\title{
GEOECOLOGICAL MARKETING OF TOURIST - RECREATIONAL ZONES OF CITIES TERRITORIES
}

\author{
Maria J. Kononova, Prof. Dr.-Eng.habil. \\ Civil Engineering Institute, St. Petersburg State Polytechnic University Peter the Great
}

\begin{abstract}
Now, practically in the all territory of the Russian Federation and, in particular, in it's Northwest federal region we can say about The Russian Renaissance with strongly pronounced elements of eclecticism. It's no coincidence, as the nature-innovative potential forces to think about investment many means on development of the real estate and tourist-recreational zones as a whole. Answering repeating questions, where are the most dangerous areas for an investment of means and for the business organization, in particular, in St.-Petersburg, even more often you are surprised to such questions, understanding that danger can proceed, first of all, from a geoecological situation on cities territories. We don't have reservations and/or divisions of administrative areas by a principle poor/rich and/or our and another's areas. You can feel genuine pride from comprehension of our deep tolerance. Means, it was possible to accept all the best, to learn to understand associates, to appreciate friendly relations, to live, without giving in to minute tendencies and the imposed stereotypes introduced by market relations.
\end{abstract}

Keywords: Sustainable development, Tourist-recreational territory, Environment assessment, allotment assignment, Tourism development, tourist-attractive, recreation infrastructure.

\section{INTRODUCTION}

From the point of view of the sustainable development the tourism is a profitable part of the budget of any country. The tourism development is a complex of common problems: allotment assignment and amenities, tourist product detection, distribution of human flows, the specialist education, organization of a transportation system and infrastructure, maintaining continuity of power supply, waste utilization, geoecological marketing of touristrecreational zones of cities territory etc.

According to above-stated there are especially actual problems, bound up with:

- detection of tourist-attractive and safe places;

- detection of places for sporting objects development and building;

- environment assessment;

- infrastructure development;

- tourist and sport objects management.

\section{SUSTAINABLE DEVELOPMENT OF TERRITORIES OF RESORT, TOURISM AND SPORT FOR CITY REGIONS}

Thus, it is necessary to create the integral tool for lowing man-hours for making concepts of terrain development in the recreational purposes, and also being a universal support instrument for detection location and designing of tourism and sports objects.
Besides the tool tested in pilot area can be transferred in other countries for the purposes of the sustainable development. The given project is dedicated to the solution of these problems.

The purpose of the project is the creation of an integral geoinformation analytical complex with the applications as 3D interpretations for tourism and sports objects of the pilot urban. And also:

- making of a methodology of reasonable detection of terrains suitable for recreational activity;

- giving recommendations of their making and usage;

- making of specific land use scheme according to recreation kinds on the basis of environment analysis;

- real estate management and expertise and the sustainable development of territories with different requirements and technical-engineer capabilities (natural, anthropogenic, technogenic).

Direction of activity:

- Application of the decision support systems for sustainable development of territories

- Engineering of the renewable energy \& water power for recreation territories

- Geoecological modeling and management of recreation infrastructure (tourism, sport, resort)

- Improvement of GIS of the recreation territory

ISSN 1691-5402 
- Databases

- Education programs for innovative engineering recreation territory use.

\section{BASIC REGULATIONS GEOECOLOGICAL ASPECTS OF TOURIST - RECREATIONAL ZONES}

In case with fast development of tourism both sports and amateur the need for development tourist recreational zones promptly increases. There are few officially accepted kinds of tourism: Foot, ski, mountain, water, bicycle, speleological, automobile, motor and ecological tourism.

At construction of objects of ecological, water, sports, speleological, extreme and other kinds of tourism, it is necessary to provide safe stay of sportsmen and having a rest, for this purpose it is necessary to consider geoecological aspects of built up territory.

Following geoecological aspects are considered:

- Nature management;

- Arrangement of a natural landscape.

The Nature management considers functionality using of built up territory, including quality estimation of an environment, limiting stability of development, geoecological risks estimation and liquidation of these risks in view of all requirements for preservation of stable geoecological safety in recreational zone all stages of its development.

Principles of maintenance of geoecological safety are based on Nature management and should be:

- based on use mainly natural resources;

- don’t putting damage to environment and don't allowing the minimal damage which undermines ecological stability of environment;

- aimed to ecological formation and education, to format attitudes of equal partnership with the nature and territorial resources of development;

Considering geoecological aspects is necessary to analyze a system decision of requirements on territory using technological process, according to rational arrangement of a natural landscape.

Arrangement of a natural landscape is provided at information of an inhabitancy, availability of decisions, liquidity of development, considering seasonal prevalence and assimilability.

Formation tourist - recreational zones passes in two stages. One is carrying out the researches of geoecological marketing and concept statement of development is necessary. The second stage is planning of construction measures an infrastructure of the zones.

The future rates of urbanization and pollution of natural landscapes constantly increasing, therefore it is necessary to follow some factors to keep and provide favorable ecological development:
- The hotels, camping's or shelters and huts where tourists stop should be located to save normal, ecologically steady development of a neighboring landscape.

- These hotels camping's should be constructed of ecologically harmless materials and their inhabitants should not excessively spend energy and water, thus drains and emissions are cleared other waste are utilized;

- Should be provided transport availability and infrastructural security.

According to geoecological aspects of development tourist - recreation zones form the preservation of quality of an inhabitancy and as consequence a basis of health and safety of sportsmen and having a rest.

\section{BASIC PRINCIPLES OF FORMATION OF TOURIST AND RECREATIONAL TERRITORIES}

As for megalopolises and city agglomerations the analysis of town-planning development is kept, and for all settlements and development area to the comparative analysis is exposed:

- climatic conditions;

- territorial structure;

- demographic situation;

- master plans of development area;

- transport infrastructures of the territory.

The tourist - recreational territory is the territory having natural, historical, cultural potential for formation of requirement in a healthy lifestyle and preservation of a sustainable development through an ecological health and safety out of production, possessing the status of the protected and kept habitat, favorably influencing on the development of real estate.

So basic principles of formation of touristrecreational territories of the historical cities both in Europe, and in Asia:

1. The existing landscape - ecological and historical - cultural frameworks are used as a basis of formation of structure of tourist and recreational zones.

2. Unprofitably used territories and real estate accustom as tourist and recreational zones and territories

3. The main priorities of specialization of tourist recreational zones, scales of their liquidity and sequence of development are formalized.

4. Formation of system of tourist - recreational zones is conducted in the conditions of the existing and formed transport infrastructure.

Anyway the main attention at the present stage is more and more paid to identity of elements and details.

Before starting using this or that model of reconstruction - renovation revitalization of the development area it is necessary to carry out 
geoecological justification for formation of system of geoecological marketing of the tourist and recreational territory subsequently. Methods and the principles of reconstruction-renovation-revitalization will depend on it:

1. Existence of real estate objects of natural and cultural heritage.

2. Condition of rare and valuable architectural planning and landscape - composite elements.

3. Valuable historical and religious environmental characteristics.

4. Unique real estate objects and monuments of architecture.
5. The protected wild types and natural landscapes, reserved zones.

\section{BASIC CONCEPTUAL PRINCIPLES OF GEOECOMARKETING}

The ways of formalizations of geoecological marketing of tourist-recreational zones of development of cities territories which are based on conceptual bases of marketing and the theory of preservation of the environment in the conditions of a sustainable development of cities territories, are presented in a general view on fig. 1 .

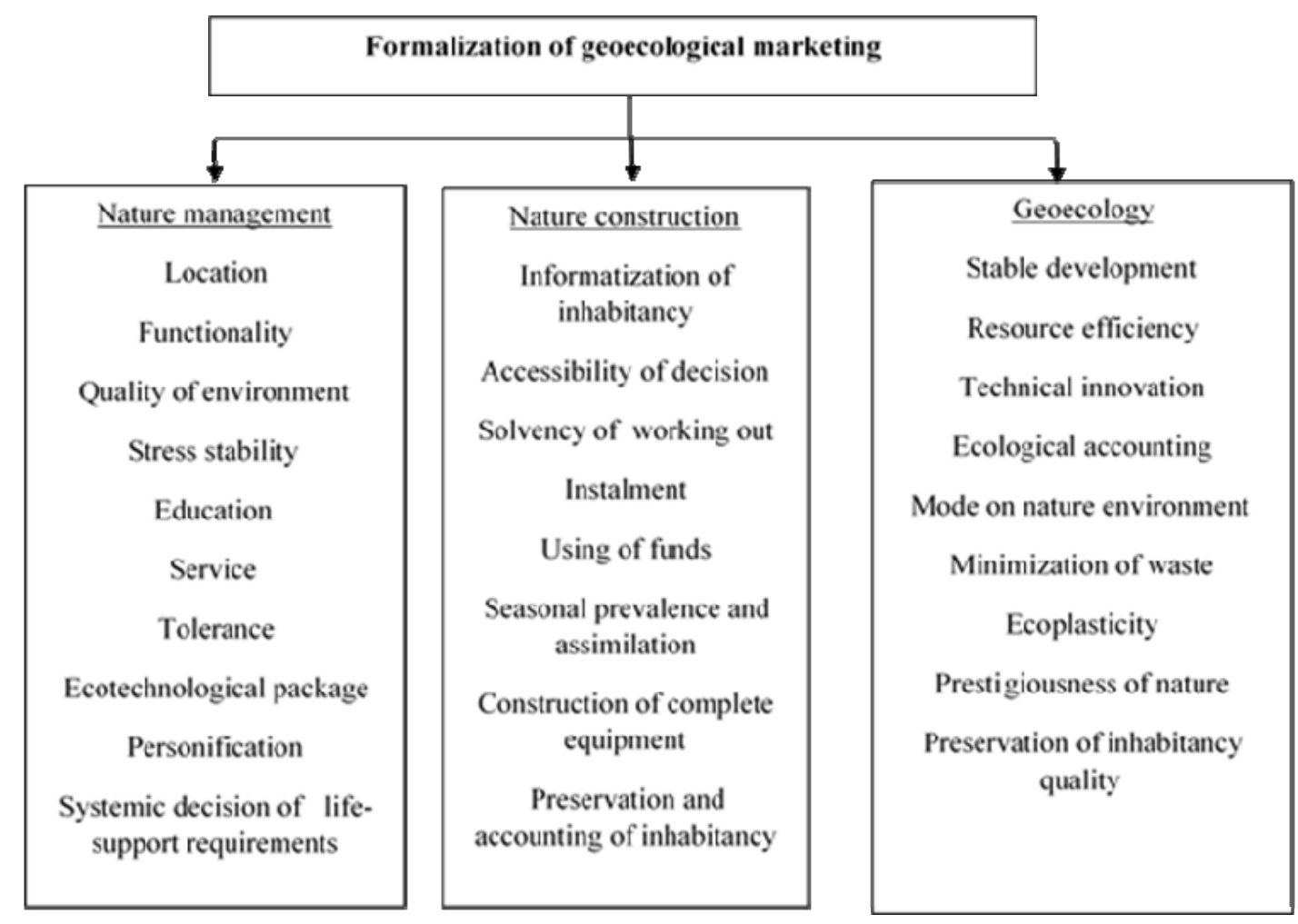

Fig.1 The ways for formalization of geoecological marketing of tourist-recreational zones of development of cities territories

Main principles of the modern concept of geoecological marketing of tourist-recreational zones of development of cities territories:

- Aiming at achievement of steady practical result of activity in borders of tourist recreational zones.

- Orientation on long-term trouble-free and safe result of work of objects of rest and leisure.

- Use of unity and interrelation of strategy and tactics of activity of tourist-recreational zones. Primary is working out and study of decisions of the strategic geoecological problems connected with a long-term sustainable development of objects of the real estate and territories of development as a whole is primary, tactics of behavior of proprietors of objects of leisure and rest in the market is under construction on the basis of the developed strategy.

- Orientation of the fixed results of work to real conditions and quality of habitat providing desires and needs of the consumer, that is activity of objects of leisure and rest is directed on satisfaction social and spiritual needs of clients. Only being based on this principle, it is possible to count on successful activity.

- Orientation to innovations. For stable and longterm development of tourist-recreational zones of cities it is necessary to provide steady quality of an inhabitancy through constant technological innovations and resource efficiency, capable to answer inquiries of consumers of services of tourism and sports objects. 
- System studying of the market of tourist branch and its conjuncture. Monitoring and market controlling has seasonal prevalence, a system and geoecological predisposition in all aspects. The timely and operative understanding of tendencies of change of a market situation and their account by strategy and tactics working out is a basis of an estimation, the analysis and the forecast of logistics of tourist streams and streams having a rest, influences of touristrecreational zones on environment.

- Ecoplasticity and/or ecotolerance at aspiration to an object in view - increase of liquidity of the real estate of tourist-recreational zones of cities territories, reached by the permanent ecological account, information of an inhabitancy in the conditions of environment change.

- The system scientific approach to consideration and the decision of problems. In geoecological marketing are used scientifically well-founded methods of research and the analysis of geoecology and the marketing theory.

- Development of marketing thinking at all employees of objects of leisure and rest zones through training, the organization of service and working out individual ecotechnological packages.

- Establishment of partner relations on mutually advantageous conditions with accessory manufacturers for acceptance of system decisions under life-support requirements. The account of mutual interests promotes adjustment of close and long-term communications, gives the chance to all subjects of the market to realize the potential for maintenance of completeness of arrangement, preservation and the environment account.

Highly professional and qualified organization of service of marketing is necessary for realization of principles of geoecological marketing in work of each concrete company and in its structure of division on geoecomarketing.

\section{THE LENINGRAD REGION DESCRIPTION}

The chosen theme of research is relevant to the regions of the Northwestern Federal District because this district is the one of the most potential in Russia in organizing tourism and recreation activities. The District has all necessary resources for these activities: historical and cultural heritage, good geographical location, beautiful landscapes, labour forces and workforces development.

At the first stage of research the existing tourism infrastructure were investigated, including hotels, food service area, transport accessibility, the interest of Russian and foreign tourists in these facilities, the possibility of on-line booking and the major factors which are retarding development of incoming tourism. To achieve these goals the most promising directions of tourism development of the Northwestern District were considered - The Volga-Baltic waterway, places of pilgrimage and business tourism.

The Leningrad Region occupies a large area in the Northwest of Russia from the Gulf of Finland to Lake Onega (Fig. 2).

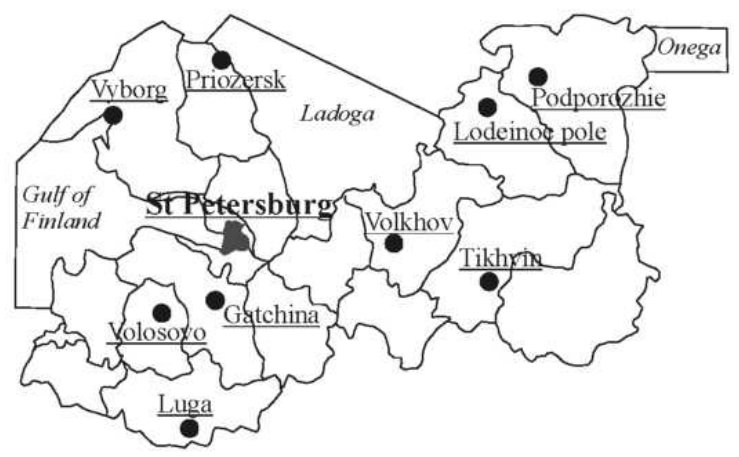

Figure 2. Diagrammatic layout of the Leningrad Region districts

The region is one of the most dynamically developing subjects of Russian Federation and consequently is attractive to many of the people. The developing tourism infrastructure, safety and proximity of Saint Petersburg attract tourists, as well as investors to region. The trends of development and monitoring of recreational zones of the Leningrad area are especially attractive in these conditions. The territory of the Leningrad region includes 350 places, attractable for the tourists. The table 1 demonstrates the recent state of infrastructure quality and the tourist load for 2004 in the Leningrad Region.

The table demonstrates that the greatest amounts of means of accommodation now have such municipal formations of the Leningrad Region, as Vyborg, Priozersk and Luga district. Gatchina and Lomonosov are objects of the most interest. There are residences of Russian tsars settle down in their territory.

Development of tourism infrastructures should be friendly for the nature and the people. It provides the geoecological analysis of territory of development. Also it necessary to consider recent and perspective design of engineering networks and communication, real-estate market and territories development, localization processes optimization.

Increase of population and economical growth of advanced countries entail step-up per capita offhours, idle time of the social groups and the sociality that averages about $30 \%$ of day-time according to several calculations. Consequently, everybody will aim to realize his off-hours including recreational time (tourism, sport etc.). Therewith town, land, rural \& industrial development decreases per capita potential recreational territories.

Thus, questions of acquisition of building land, architectural and landscape design, management and 
development of recent and future recreational areas, making new recreational resources become a very important (Fig. 3). Especially it is a vital question for heavily populated areas like the Leningrad Region.

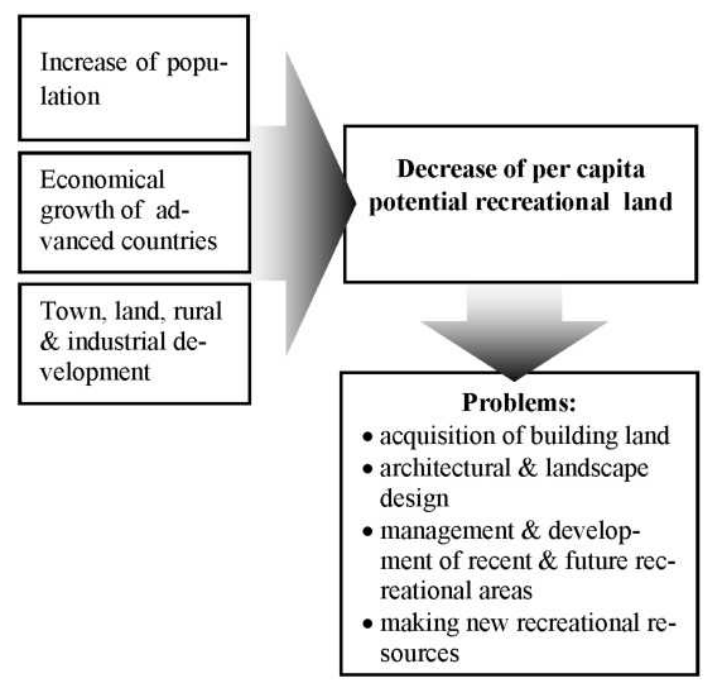

Figure 3. Effectiveness function of geoecological analysis within DSS

Organization, operating and developing of recreational zones of tourism and sports objects, and their interplay with residential, industrial, nature protection and other zones is necessary to conduct with allowance for many components:

- the schedules of the area perspective development;

- a geographic setting;

- climatic conditions;

- a level of development of an infrastructure and industry;

- location of the residential districts;

- density of population;

- availability of a cultural-historical value;

- traditions of the population and etc.

Besides many recreation kinds demand availability especial residing conditions: climatic (for example, seaside health resorts), landscape (for example, mounting skiing resorts), circumstance by resources (for example, hunting, fishery). The relevant factors are the transport accessibility, seasonal predilection and potential selectivity of the population on recreation kinds. Seasonal usage only of recreational objects is a great problem for developers and managers of this object in conditions of market economy. Thus, it is necessary to select season compossible recreation kinds with allowance for of psychological comfort and whenever possible by similar modes of operation. In this connection it is necessary to envisage a legible zoning of recreational territories with allowance for time of usage for rest (long-lived short-lived) and duration of work (yearround, seasonal), kinds of strain-relief crystallization, social and age composition of the people. The special attention should be given to a geoecological estimation of the territories, which is directional on definition of methods and means of the sustainable development of the recreational zones.

The information basis of GIS is electronic maps of a particular town or region. The map objects of a type (for instance, buildings, blocks, streets) are grouped into so-called information layers. The figure 4 demonstrates the key macrolayers of GIS-based DSS which are required for sustainable quality infrastructures and quantity management of tourism in the urbanized and nature area of the Leningrad Region. Every macrolayer presents a group of thematic layers of homogeneous objects. The landscape layer which is base of the system includes surface relief. The hydrological network contains natural and artificial surface and ground water bodies. Environmental conditions are a very important because they directly influent on type of recreational resource. The most of localities inside recreational areas are a recreational resource or a place of accommodation. Good quality of infrastructure and route networks is sine qua non for negotiability and boosts of the recreational areas. Well-working tourist and sport objects as well as routes are the goal of DSS.

\section{CONCLUSION}

Creation of modules of geoecological marketing for formation and arrangement of tourist-recreational zones of new generation of the globalized culture taking into account local color and natural conditions of landscape support of nature-climatic zoning of city territories is aimed at improvement and maintenance of innovative possibilities of operation of touristrecreational zones of various qualitative and area characteristics, the dynamic and static loading, the determined and stochastic processes of operation of infrastructures. Developers and realtors should also know the characteristics of the territory around the object: its ecological indicators, traffic location, level of the infrastructure development etc.

1. Now the accounting of a water resource is defining at a geoecomarketing of development territories.

2. Absence of geoecomarketing doesn't allow to provide stability of development of tourism.

3. The account of geoecomarketing is necessary at formation of price estimations of territories of building of objects of tourism and sports.

4. Using of geoecomarketing - activity, service, product - forms the stable market with maintenance of seasonal geoecological safety.

5. Realization of geoecomarketing of leisure and rest territories raises target appeal of tourist branch. 
Table 1. Number of collective accommodation objects of the Leningrad Region and its saturation points on 01.01.2005. (www.lentravel.ru, the information-statistical collection 2005. Tourism development of Leningrad region in 2000-2004 and the forecast for 2005. The statistical account and the analysis in tourism sphere of Leningrad region.)

\begin{tabular}{|c|c|c|c|c|c|c|c|c|c|c|}
\hline \multirow{3}{*}{$\begin{array}{l}\text { Leningrad Region } \\
\text { and districts }\end{array}$} & \multirow{3}{*}{$\begin{array}{l}\text { Total area of the } \\
\text { region /district } \\
{\left[\mathrm{km}^{2}\right]}\end{array}$} & \multirow{3}{*}{$\begin{array}{l}\text { Total popu- } \\
\text { lation }\left[10^{3} \text { the }\right. \\
\text { inhabitants] }\end{array}$} & \multicolumn{2}{|c|}{$\begin{array}{c}\text { Collective means of } \\
\text { accommodation (CMA) }\end{array}$} & \multicolumn{6}{|c|}{ Including } \\
\hline & & & \multirow{2}{*}{ 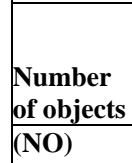 } & \multirow{2}{*}{\begin{tabular}{|l}
$\begin{array}{c}\text { Seats of ac- } \\
\text { commodation } \\
\text { /Beds }\end{array}$ \\
(SA/B)
\end{tabular}} & \multicolumn{2}{|c|}{$\begin{array}{l}\text { Organisations } \\
\text { of a hotel type }\end{array}$} & \multicolumn{2}{|c|}{$\begin{array}{l}\text { Sanatorium } \\
\text { and resorts }\end{array}$} & \multicolumn{2}{|c|}{$\begin{array}{l}\text { Organisations } \\
\text { of rest }\end{array}$} \\
\hline & & & & & NO & SA/B & NO & SA/B & NO & SA/B \\
\hline Leningrad Region & 85,900 & 1659.90 & 432 & 44,422 & 66 & 3505 & 13 & 1442 & 353 & 39,475 \\
\hline Volosovsky District & 2680.50 & 47.10 & 5 & 485 & 1 & 40 & 0 & 0 & 4 & 445 \\
\hline Volkhov District & 5043.20 & 54.50 & 8 & 410 & 2 & 100 & 1 & 100 & 5 & 210 \\
\hline Volkhov & 108.21 & 50.50 & 5 & 329 & 4 & 229 & 1 & 100 & $\mathbf{0}$ & $\mathbf{0}$ \\
\hline Vyborg District & 7431.20 & 176.20 & 85 & 10,150 & 16 & 701 & 0 & $\mathbf{0}$ & 69 & 9449 \\
\hline Gatchina & & & 5 & 267 & 3 & 177 & 2 & 90 & $\mathbf{0}$ & $\mathbf{0}$ \\
\hline Gatchina District & 2864 & 114.70 & 17 & 2729 & 2 & 74 & 0 & $\mathbf{0}$ & 15 & 2655 \\
\hline Lodeinopolsky District & 4911 & 39.80 & 19 & 721 & 3 & 198 & 0 & $\mathbf{0}$ & 16 & 523 \\
\hline Luga District & 6025 & 86.70 & 41 & 7696 & 1 & 68 & 2 & 265 & 38 & 7363 \\
\hline Podporozhsky District & 7705 & 38.90 & 7 & 195 & 2 & 58 & 0 & 0 & 5 & 137 \\
\hline Priozersk District & 3597 & 38.90 & 109 & 10,029 & 4 & 126 & 1 & 350 & 104 & 9553 \\
\hline Tikhvin District & 822 & 77.4 & 12 & 486 & 1 & 150 & 0 & 0 & 11 & 336 \\
\hline
\end{tabular}
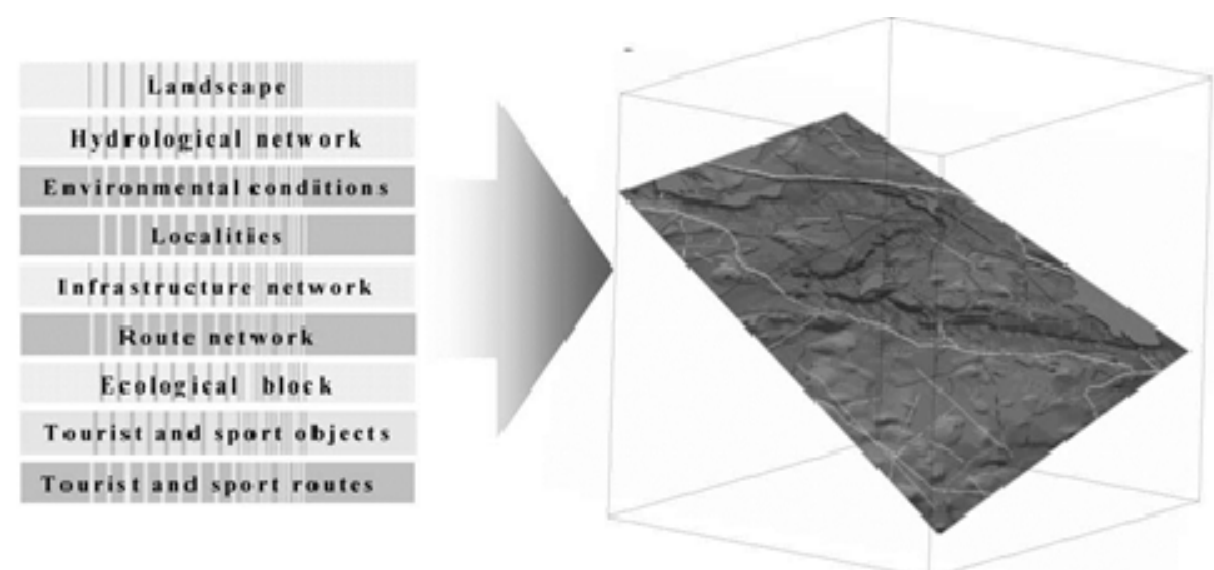

Figure 4. Thematic macrolayers of GIS - based DSS for sustainable quality infrastructures and quantity management of tourism in the urbanized and nature area.

\section{REFERENCES}

[1] Kononova M.J. "The development of local territorial basin monitoring”, Journal Science Technical Lists, St.Petersburg, SPSTU, vol. 14, 1998, pp. 45-51.

[2] Kononova M.J. () "On the problem of LCAM results visualization”, Journal Science Technical Lists, St.Petersburg, SPSTU, vol. 21, 2000, pp. 116-127.

[3] Kononova, M. Yu. \& Nikonova, O.G. "About use of threedimensional interpretations as support of the perspective forms of use of a nature.” Regional Ecology 3/4 (15), 2000, pp.7-12.

[4] Nikonova, O.G. \& Kononova, M. Yu. "Inspiration of geosphere situation for functioning of HPS.” Journal Science Technical Lists, 2000, pp.131-137.
[5] Kononova, M.J. "Multiple-stage visualization of nature use for the strategic development and environmentally friendly activity." Working Papers submitted as part of the Specialist Workshop on "Environmental Protection, Sustainability and Information - Regional Approaches in the Baltic Sea Region” Held in Saint-Petersburg, Russia, 22-24 February, 2001. Hamburg, BEIDS, 2001 pp.79-92.

[6] Kononova M.Yu. "Geoecological Analysis Methodology of Hydroelectric Power Stations and Their Cascades", Dr. Eng.habil. Dissertations, Saint-Petersburg State Polytechical University, 2002. $290 \mathrm{P}$

[7] Kononova M.Yu. "Geoecological Analysis Methodology of Hydroelectric Power Stations and Their Cascades", Dr. Eng.habil. Dissertations, Saint-Petersburg State Polytechical University, 2002. <URL:http://dl.unilib.neva.ru/dl/186.pdf>. 
[8] Kononova M.Yu., Nikonova O.G. "How to Prepare Tourist Recreational Unites of Development Areas on the Basis of Arc View 9.0", Paper of Scientific and Practical Conference "Formation of Technical Policy of Innovation Hi-Tech Technologies”, Saint-Petersburg State Polytechical University, 2005. pp. 44-49.

[9] Kononova M.J. "Ecology. Ecological Basic Foundation of Tourist and Sport Objects.” Saint-Petersburg State Polytechical University, 2006. $94 \mathrm{P}$.

[10] Kononova M.Yu., Nikonova O.G., Pirozhok P.P. Chapter 15 "Sustainnable Development for the Real-Estate Management of Resort, Sport and Tourism Objects” pp. 283-303 , Book Innovation, Education and Communication for Sustainable Development. Walter Leal Filho (ed.) Band 24. Frankfurt am Main - Berlin - Bern - Bruxelles - New York Oxford - Wien, Peter Lang Europäischer Verlag der Wissenschaften. 2006. $766 \mathrm{P}$.

[11] Kononova M.J., Nikonova O.G. "Sustainable Development of Territories of Resort, Tourism and Sport for City Regions", The VII International Environmental Forum "Baltic SEA DAY 2006” St. Petersburg March 21-23, 2006. Book of Proceedings. Pp. 340-341.

[12] Kononova M.Yu., Martjugina I.V. "Hydro-Informatics in Recreational Development of Territory of Resorts, Tourism and Sport.” The VI International Youth Environmental Forum “Ecobaltica 2006” St. Petersburg June 27-29, 2006. Book of Proceedings. Pp. 51-54.

[13] Kononova M.Yu., Nikonova O.G., Pirozhok P.P. "Organization of Space of Development for Water Tourism of the Nord-West Russia.” The VI International Youth Environmental Forum “Ecobaltica 2006” St. Petersburg June 27-29, 2006. Book of Proceedings. Pp. 109-112.

[14] Kononova M.J. “About geoecological Marketing of sustainable Development of recreational Zones of Territories of Development of tourist-recreational Zones of Cities Territories”, The VIII International Environmental Forum “Baltic SEA DAY 2007” St. Petersburg March 21-23, 2007. [23]
[15] Kononova M.Yu., Martyugina I.V. "Using of geothermal energy on Tourism-recreational Zones Objects of North West Region”, The VIII International Environmental Forum "Baltic SEA DAY 2007” St. Petersburg March 21-23, 2007. Book of Proceedings. Pp. 550-552.

[16] Ryachovskaya A.A., Kononova M.J. “Geoecological Aspects of recreational Zones of Territories of Development of Tourism as the Basis of Healyh and Well-Being of Sportsmen and Having a Rest", The VIII International Environmental Forum "Baltic SEA DAY 2007” St.Petersburg March 21-23, 2007. Book of Proceedings. PP.484-489.

[17] Martjugina I.V., Kononova M.Y. “Application of geothermal Power on Tourism and Recreation zones Object in NorthWestern Russia”, Work from Saint-Petersburg State Polytechical University, St.Petersburg, SPSTU, vol. 502, pp. 210-220.

[18] Kononova M.Yu., Nikonova O.G. "Geoecological Formalization of 3D Visualization for Real Estate Development of the recreational Zones", Work from SaintPetersburg State Polytechical University, St. Petersburg, SPSTU, 2007, vol. 502, pp. 373-379.

[19] Kononova M.J. “On geoecological Marketing of sustainable Development of tourist-recreational zones within Development Territories of Cities”, Journal Science Technical Lists, St. Petersburg, SPSTU, 2008, vol. 70, pp. 142-148.

[20] Kononova M.J. "Infrastructure of tourism and recreations of water system of Volga-Baltic waterway." The XIII International Environmental Forum "Baltic SEA DAY 2012" St. Petersburg. March 19-23, 2012. Book of Proceedings. 2012. PP. 183-185, 468-470.

[21] Kononova M.J. "Ecology. Ecological Basic Foundation of Tourist and Sport Objects." Saint-Petersburg State Polytechical University, 2014, 186 P.

[22] Kononova M.J. "Ecology. Ecological Basic Foundation of Tourist and Sport Objects.” Saint-Petersburg State Polytechical University, 2014

<URL:http://dl.unilib.neva.ru/dl/2/3910.pdf> 